\title{
Diverse Effects of Lead Nitrate on the Proliferation, Differentiation, and Gene Expression of Stem Cells Isolated from a Dental Origin
}

\author{
Mariam Abdullah,, ${ }^{1}$ Fazliny Abd. Rahman, ${ }^{1}$ Nareshwaran Gnanasegaran, ${ }^{1}$ \\ Vijayendran Govindasamy, ${ }^{2}$ Noor Hayaty Abu Kasim, ${ }^{1}$ and Sabri Musa ${ }^{3}$ \\ ${ }^{1}$ Department of Conservative Dentistry, Faculty of Dentistry, University of Malaya, 50603 Kuala Lumpur, Malaysia \\ ${ }^{2}$ Hygieia Innovation Sdn. Bhd, Lot 1G-2G, Komplex Lanai, No. 2, Persiaran Seri Perdana, Persint 10, 62250 Putrajaya, Malaysia \\ ${ }^{3}$ Department of Children's Dentistry and Orthodontics, Faculty of Dentistry, University of Malaya, 50603 Kuala Lumpur, Malaysia
}

Correspondence should be addressed to Mariam Abdullah; mariamabd@um.edu.my and Vijayendran Govindasamy; vijay@hygieiagroup.com

Received 7 August 2013; Accepted 27 October 2013; Published 28 January

Academic Editors: C. Garcia, C. Montoliu, J.-M. Sabatier, and A. Yasutake

Copyright (C) 2014 Mariam Abdullah et al. This is an open access article distributed under the Creative Commons Attribution License, which permits unrestricted use, distribution, and reproduction in any medium, provided the original work is properly cited.

Lead $\left(\mathrm{Pb}^{2+}\right)$ exposure continues to be a significant public health problem. Therefore, it is vital to have a continuous epidemiological dataset for a better understanding of $\mathrm{Pb}^{2+}$ toxicity. In the present study, we have exposed stem cells isolated from deciduous and permanent teeth, periodontal ligament, and bone marrow to five different types of $\mathrm{Pb}^{2+}$ concentrations $(160,80,40,20$, and $10 \mu \mathrm{M})$ for 24 hours to identify the adverse effects of $\mathrm{Pb}^{2+}$ on the proliferation, differentiation, and gene expression on these cell lines. We found that $\mathrm{Pb}^{2+}$ treatment altered the morphology and adhesion of the cells in a dose-dependent manner. There were no significant changes in terms of cell surface phenotypes. Cells exposed to $\mathrm{Pb}^{2+}$ continued to differentiate into chondrogenesis and adipogenesis, and a severe downregulation was observed in osteogenesis. Gene expression studies revealed a constant expression of key markers associated with stemness (Oct 4, Rex 1) and DNA repair enzyme markers, but downregulation occurred with some ectoderm and endoderm markers, demonstrating an irregular and untimely differentiation trail. Our study revealed for the first time that $\mathrm{Pb}^{2+}$ exposure not only affects the phenotypic characteristics but also induces significant alteration in the differentiation and gene expression in the cells.

\section{Introduction}

Lead $\left(\mathrm{Pb}^{2+}\right)$ is regarded as one of the most toxic substances among heavy metals. It is derived from the environment as well as an industrial pollutant. $\mathrm{Pb}^{2+}$ causes serious illness which covers not only physiological and biochemical dysfunctions but also behavioural dysfunctions in humans [1,2]. The impact is more prevalent in children [3] who have a high tendency to accumulate $\mathrm{Pb}^{2+}$ in their circumpulpal dentin [4]. The common route of exposure of $\mathrm{Pb}^{2+}$ is in the blood and eventually it is deposited in the hard tissues such as bone and teeth. The deposition in the latter tissue is permanent [5]. Therefore, teeth can be a useful long-term record of $\mathrm{Pb}^{2+}$ accumulation [6] and have been used as biological markers to environmental pollution [7-15].

Several factors are identified which influence the $\mathrm{Pb}^{2+}$ deposition in teeth. These include types of teeth and the presence of caries. The deposited $\mathrm{Pb}^{2+}$ in teeth during mineralization is largely retained since the teeth have hard stable tissues [16]. $\mathrm{Pb}^{2+}$ is distributed with the highest concentration in the circumpulpal dentin which is located in the innermost layer of dentin, adjacent to the dental pulp. The mechanism by which $\mathrm{Pb}^{2+}$ is deposited within the matrix of the primary and circumpulpal dentin is not clear although both primary and circumpulpal dentins accumulate $\mathrm{Pb}^{2+}$ with increased exposure and with postnatal age [17]. Nevertheless, it has 
been suggested that the deposition of $\mathrm{Pb}^{2+}$ in teeth is probably due to the similar oxidation number of both $\mathrm{Ca}^{2+}$ and $\mathrm{Pb}^{2+}$ ions. Studies also have shown that the toxicity effect of $\mathrm{Pb}^{2+}$ becomes apparent due to the ability of the metabolic cation $\mathrm{Pb}^{2+}$ to bind with specific ligands of biomolecular substances that play a vital role in various physiological functions [18, 19]. It also competes with ion transport and interferes with normal physiology [20]. There are also studies on the effect of $\mathrm{Pb}^{2+}$ on cells derived from human periodontal ligament [21]. This is due to availability of material and because of the incorporation of elements into the mineral phase of dental tissues [22].

Stem cells play an important role in maintaining the homeostasis and function of tissues and play a pivotal role in dealing with invaders such as $\mathrm{Pb}^{2+}$. This effect has been documented in previous work that described the effects of $\mathrm{Pb}^{2+}$ on dental cells [23].

We have studied the effects of various types of stem cells from a dental origin, namely, from deciduous teeth (SCDs), permanent teeth (DPSCs), and periodontal ligament (PDLs) as well as from bone marrow (BM-MSCs) against various $\mathrm{Pb}^{2+}$ concentrations with respect to their proliferation, multilineage differentiation capacity, and gene expression level. Interestingly, though all stem cells are almost similar to each other, we discovered significant differences in terms of proliferation and differentiation of stem cells derived from SCD, DP, PDL, and BM.

\section{Materials and Methods}

2.1. Tissue Collection and Isolation of Cells. This work was approved by the Medical Ethics Committee, Faculty of Dentistry, University of Malaya (medical ethics clearance number: DF CO1107/0066 (L)). All the subjects consented to the study. All subjects were nonsmokers, nonalcoholics, and free from any infectious diseases such as HIV, HBV, and HCV.

Bone Marrow (BM) stem cells or mesenchymal stem cells (MSCs) cultures were established from three donors (age: 24-35) as previously described [24]. Briefly, $60 \mathrm{~mL}$ BM was aspirated aseptically from the iliac crest of each patient under deep sedation. All processings of samples were done inside a class 100 biosafety hood. The BM was diluted (1:1) with knockout Dulbecco's modified Eagle's medium (KO-DMEM; Invitrogen, Carlsbad, CA, USA; http://www.invitrogen.com/) and centrifuged at $1800 \mathrm{rpm}$ for 10 minutes to remove anticoagulants and other debris. The supernatant was discarded and the BM washed once with the culture medium. Mononuclear cells (MNCs) were isolated by layering onto a lymphoprep density gradient $(1: 2$; AxisShield PoCAS). The MNCs present in the buffy coat were washed again with the culture medium. The mononuclear fractions that also contained MSCs were plated into culture flasks.

Dental pulp stem cells (DPSCs) cultures were established from sound intact third molars from adults (age: 24-35) and deciduous (SCDs) were established from molars from children (age: 3-12) as previously described [25]. Periodontal ligament (PDLs) tissues were separated from the root surface of deciduous teeth using a sterilized scalpel. Briefly, root surfaces were cleaned with Povidone-iodine (Sigma Aldrich, St. Louis, MO, USA; http://www.sigmaaldrich.com) and the pulp was extirpated within two hours of postextraction and then processed as follows. The pulp tissues as well as PDL tissues were minced into small fragments prior to digestion in a solution of three $\mathrm{mg} / \mathrm{mL}$ collagenase type I (Gibco, Grand Island, NY, http://www.invitrogen.com) for 40 minutes at $37^{\circ} \mathrm{C}$. After neutralization with a $10 \%$ Fetal Bovine Serum ( FBS, Fetal Bovine Serum, (FBS) (Hyclone; Thermo Scientific Inc, Waltham, MA; http://www.thermoscientific.com), the cells were centrifuged and were seeded in a culture flask.

All cells were cultured in an identical culture condition videlicet, in $T 75 \mathrm{~cm}^{2}$ culture flasks (BD Pharmingen, San Diego CA, USA; http://www.bdbiosciences.com) with a culture medium containing KO-DMEM, $0.5 \%$ and $10000 \mu \mathrm{g} / \mathrm{mL}$ of penicillin/streptomycin (Invitrogen), 1\% 1x Glutamax (Invitrogen) and $10 \%$ FBS with a humidified atmosphere of $95 \%$ of air, and $5 \%$ of $\mathrm{CO}_{2}$ at $37^{\circ} \mathrm{C}$. Nonadherent cells were removed $48 \mathrm{~h}$ after initial plating. The medium was replaced every three days until the cells reached $80-90 \%$ confluency.

2.2. Preparation of $\mathrm{Pb}^{2+}$. The stock concentration of $\mathrm{Pb}^{2+}$ was prepared by dissolving $\mathrm{Pb}^{2+}$ nitrate $\left(\mathrm{Pb}\left[\mathrm{NO}_{3}\right]_{2}\right)$ (Cat No 203580, Sigma Aldrich) in distilled water at a concentration of $10^{-4} \mathrm{M}$. A total of 5 different $\mathrm{Pb}^{2+}$ concentrations $(160,80,40$, 20 , and $10 \mu \mathrm{M}$ ) were used in this study with $50 \%$ ratio between each concentration. The concentration of $\mathrm{Pb}^{2+}$ was designed based on previous study [26].

2.3. Exposure of Cell Lines to $\mathrm{Pb}^{2+}$. The BM-MSCs, SCDs, DPSCs, and PDLs were seeded at 1000 cells $/ \mathrm{cm}^{2}$ in the 6well plates (BD Bioscience) and allowed to grow for 96 hours. Then freshly prepared $\mathrm{Pb}^{2+}$ solution was added into the culture media to obtain the aforesaid concentration. Exposed cells were cultured for 24 hours before they were used for the subsequent experiments.

2.4. Growth Kinetics. Exposed cell lines with $\mathrm{Pb}^{2+}$ were counted and assessed for viability using a trypan blue dye exclusion technique. The population doubling time (PDT) of $\mathrm{Pb}^{2+}$ exposed BM-MSCs, PDLs, SCDs, and DPSCs were analyzed using the formula:

$$
\mathrm{PDT}=\frac{t \mathrm{plg} 2}{(\lg \mathrm{NH}-\lg \mathrm{N})},
$$

where $\mathrm{NI}$ is the inoculum cell number, $\mathrm{NH}$ is the cell harvest number, and $t$ is the time of the culture (in hours).

2.5. MTT Assay. MTT assay was performed as described previously [27]. Each experiment was done in triplicate. The relative cell viability (\%) related to control wells containing cell culture medium without nanoparticles or PBS as a vehicle was calculated by $[A]$ test $/[A]$ control $\times 100$, where $[A]$ test is the absorbance of the test sample and $[A]$ control is the absorbance of control sample. 
2.6. LDH Assay. LDH assay was performed as described previously [27]. Each experiment was done in triplicate. The spectrophotometer was calibrated to zero absorbance using culture medium without cells. The relative $\mathrm{LDH}$ leakage (\%) related to control wells containing cell culture medium without nanoparticles or PBS as a vehicle was calculated by $[A]$ test $/[A]$ control $\times 100$, where $[A]$ test is the absorbance of the test sample and $[A]$ control is the absorbance of the control sample.

2.7. Senescence Associated with $\beta$-Galactosidase Assay. The $\mathrm{Pb}^{2+}$ exposed BM-MSCs, PDLs, SCDs, and DPSCs were tested for senescence-associated $\beta$-galactosidase (SA- $\beta$ gal) staining with the SA- $\beta$ gal staining kit (Sigma Aldrich) and used according to the manufacture's instructions. Briefly, all cell lines were washed twice with DPBS $\left(-\mathrm{Ca}^{2+},-\mathrm{Mg}^{2+}\right.$, Invitrogen) and incubated with $1 \mathrm{x}$ fixative solution for 15 minutes at room temperature. Subsequently, the fixed cells were rewashed using $2 \mathrm{~mL}$ of DPBS $\left(-\mathrm{Ca}^{2+},-\mathrm{Mg}^{2+}\right.$, Invitrogen) and stained with $1 \mathrm{~mL}$ of the staining solution mixture overnight at $37^{\circ} \mathrm{C}$ in a dry incubator. The development of the blue colour was observed under a phase contrast microscope and the quantitative analyses of the SA- $\beta$ gal staining were done by counting the percentage of blue-stained cells that represent senescence cells in the selected field of each sample.

2.8. Immunophenotyping Analysis. $\mathrm{Pb}^{2+}$ exposed cell lines were subjected to immunophenotyping analysis by using a flow cytometry. A total volume of $200 \mu \mathrm{L}$ of a cell suspension $\left(1 \times 10^{5}\right.$ cells $)$ was incubated with the labeled antibodies in the dark for 1 hour at $37^{\circ} \mathrm{C}$. The following antibodies were used to mark the cell surface: epitopes-CD90-phycoerythrin (PE), CD44-PE, CD73-PE, CD166-PE and CD34-PE, and CD45Fluoro-isothyocyanate (FITC), and HLA-DR-FITC (all from $\mathrm{BD}$ Pharmingen). All the analyses were standardized against a negative control of cells incubated with isotype-specific IgG1PE and IgG1-FITC (BD Pharmingen). At least 10,000 events were acquired on Guava Technologies flow cytometer and the results were analyzed using Cytosoft, Version 5.2, from Guava Technologies.

2.9. Differentiation Assay. The $\mathrm{Pb}^{2+}$ exposed cell lines were replated at a density of 1000 cells $/ \mathrm{cm}^{2}$ in 6-well plates and were grown to confluence and subjected to differentiation into adipogenic, chondrogenic, and osteogenic lineages according to the method described earlier [24]. The adipogenic lineage was initiated in a 3-week culture period by inducing the cells with $10 \%$ FBS, $200 \mu \mathrm{M}$ indomethacin, $0.5 \mathrm{mM}$ 3-Isobutyl-1-methylxanthine (IMBX), $10 \mu \mathrm{g} / \mathrm{mL}$ insulin, and $1 \mu \mathrm{M}$ dexamethasone (all reagents from Sigma Aldrich). Lipid droplets were visualized by staining with Oil Red O staining (Sigma Aldrich). For the chondrogenesis differentiation, the cells were cultured in a media supplemented with ITS +1 (Sigma Aldrich), $50 \mu \mathrm{M}$ of L-ascorbic acid-2 phosphates, $55 \mu \mathrm{M}$ of sodium pyruvate (Invitrogen), $25 \mu \mathrm{M}$ of L-proline (Sigma Aldrich), and $10 \mathrm{ng} / \mathrm{mL}$ of the transformation growth factor-beta (TGF- $\beta$ ) (Sigma Aldrich). Assessment of the proteoglycans accumulation was visualized by the Alizarin Blue staining (Sigma Aldrich). The osteogenic differentiation was stimulated in a 3-week culture period in a media supplemented with $10 \% \mathrm{FBS}, 10^{-7} \mathrm{M}$ dexamethasone, $10 \mathrm{mM}$-glycerol phosphate (Fluka, Buchs, Switzerland), and $100 \mu \mathrm{M}$ of L-ascorbic acid-2 phosphate. The assessment of calcium accumulation was visualized by using the von Kossa staining technique (Sigma Aldrich).

2.10. Reverse Transcription Polymerase Chain Reaction (RT$P C R)$. Total RNA from $\mathrm{Pb}^{2+}$ exposed BM-MSCs, PDLs, SCDs, and DPSCs was isolated with Trizol (Invitrogen) and used according to the manufacturer's instructions. The RNA of the $\mathrm{Pb}^{2+}$ exposed cells was converted to cDNA with Superscript II to reverse transcriptase (Invitrogen) and used according to the manufacturer's instructions. cDNA amplification was performed in a thermocycler at $94^{\circ} \mathrm{C} / 1 \mathrm{~min}$, a $58^{\circ} \mathrm{C} / 30 \mathrm{sec}$, and $72^{\circ} \mathrm{C} / 1 \mathrm{~min}$. The expressions of ectoderm, endoderm, and pluripotent genes were quantified in duplicate with SYBR green master mix (Applied Biosystem, Foster City, CA, USA). For data analysis, the comparative CT method was used. For RT-PCR, the products were resolved on 1.5\% agarose (Invitrogen) gel and was run in $1 \mathrm{x}$ Tris borate-EDTA buffer. The primer sequences are tabulated in Supplementary Table 1 (see the Supplementary Materials available online at http://dx.doi.org/10.1155/2014/235941).

2.11. Soft Agar Colony Formation Assay. BM-MSCs, PDLs, SCDs, and DPSCs cells exposed to $\mathrm{Pb}^{2+}$ were tested for soft agar assay colony formation assay (Cells Biolab, INC) and used according to the manufacture's instructions. Basically the $\mathrm{Pb}^{2+}$ exposed cell lines $(160 \mu \mathrm{M})$ and control (HeLa cells) were seeding in a layer of $0.35 \%$ agar DMEM/FBS over a layer of $0.5 \%$ agar/DMEM/FBS. Cultures were maintained in a humidified $37^{\circ} \mathrm{C}$ incubator. On day 7 and day 30 after seeding, cells were fixed with pure ethanol containing $0.05 \%$ crystal violet and colony forming efficiency quantified by phase contrast microscope [28].

2.12. Statistical Analysis. The descriptive statistical analyses were performed using the software SPSS for Windows (Version 18.0, SPSS Predictive Analytics, Chicago). Data is presented as mean \pm standard deviation (SD). Statistical comparisons were made using Student's $t$-test and $P$ values $P<0.05$ which were considered to be significant.

\section{Results}

3.1. Morphology of Cells Exposed to $\mathrm{Pb}^{2+}$. BM-MSCs, SCDs, DPSCs, and PDLs cultured in controlled conditions maintained a small and spindle-shape morphology and a similar observation was seen in cells exposed to $10 \mu \mathrm{M}$ of $\mathrm{Pb}^{2+}$ (Figure 1). However, BM-MSCs began to canalize and loose its cell texture and shape as well as displaying granule-like structures as the concentration of $\mathrm{Pb}^{2+}$ increased to $160 \mu \mathrm{M}$. SCDs, DPSCs, and PDLs exhibited similar appearances but with a lesser degree. 


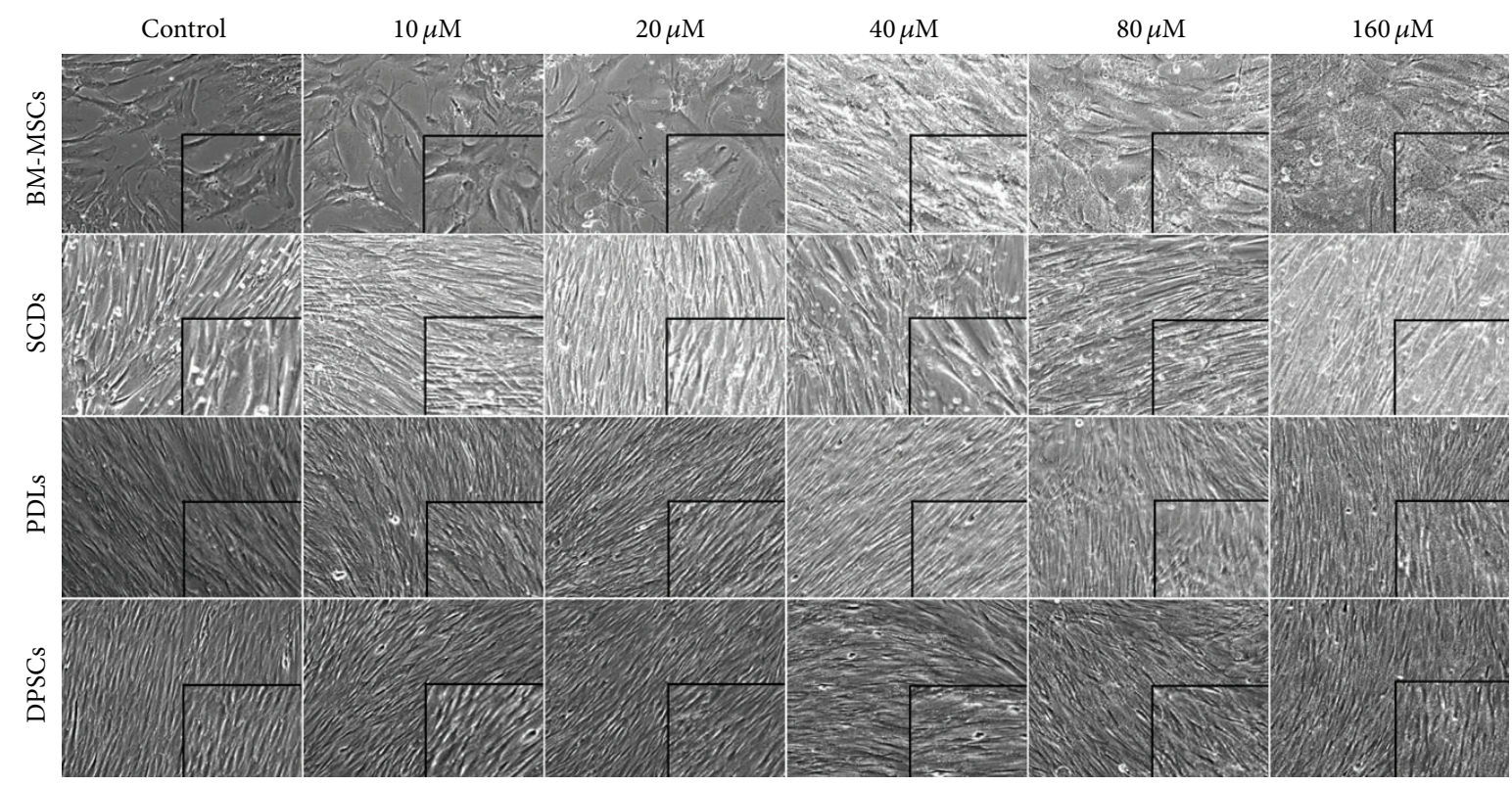

Figure 1: Cytotoxic effect of $\mathrm{Pb}^{2+}$ to bone marrow mesenchymal stem cells (BM-MSCs), deciduous stem cells (SCDs), periodontal ligament stem cells (PDLs), and permanent stem cells (DPSCs); phase contrast microscope; 10x magnification of BM-MSCs, SCDs, PDLs, and DPSCs in presence of various concentrations of $\mathrm{Pb}^{2+}$. In all experiments, the results represent average of five culture replicates with standard deviation and a representative photomicrograph was given for each experiment.

3.2. $\mathrm{Pb}^{2+}$ Reduces the Proliferation Rate of BM-MSCs as Compared to Other Cell Lines. The $10 \mu \mathrm{M} \mathrm{Pb}^{2+}$ treatment did not significantly $(P>0.05)$ inhibit the proliferation rate of any of the cell lines. However, a drastic inhibition of cell growth was observed in BM-MSCs exposed to $20 \mu \mathrm{M} \mathrm{Pb}^{2+}$ (cell count: $1.3 \times 10^{6}$ cells; MTT: 0.98 absorbance; LDH: $136 \%$; $P<0.05$ ) and up to $160 \mu \mathrm{M} \mathrm{Pb}^{2+}$ treatment (cell count: $0.6 \times$ $10^{6}$ cells; MTT: 0.24 absorbance; LDH: $\left.164 \% ; P<0.05\right)$. While SCDs and DPSCs have constant rates of inhibition of cell growth, PDLs seem to be resistant to $\mathrm{Pb}^{2+}$ exposure. A small variation was observed in the control versus cells exposed to $160 \mu \mathrm{M}$ (cell count: $7.10 \times 10^{5}$ cells; MTT: 0.78 absorbance; LDH: $146 \% ; P>0.05$ ) (Table 1). This result was reflected in the aging of cells. The percentage of SA- $\beta$ gal activity was increased in a concentration-dependent manner in all cell lines with the highest in BM-MSCs (ratio) followed by SCDs, DPSCs, and PDLs (Figure 2).

3.3. $\mathrm{Pb}^{2+}$ Alters the Expression of CD166 Marker Although Other Cell Surface Markers Remain Unchanged. Table 2 summarizes the immunophenotyping analysis of eight cell surface markers, namely, CD166, CD90, CD73, CD45, CD44, CD34, HLA-DR, and 7-AAD, from all sources of MSCs with the expression pattern being consistent throughout the $\mathrm{Pb}^{2+}$ concentrations. All four sources of MSCs in the control and $\mathrm{Pb}^{2+}$ treatments were found to be negative for the hematopoietic markers (CD34, CD45, and HLA-DR). On the other hand, a similar result was reported for the positive for cell surface markers (CD44, CD73, and CD90) among all the MSCs sources. Astonishingly, while the expressions of CD166 remain unchanged in BM-MSCs, DPSCs, and PDLs, it was lower in SCDs in $\mathrm{Pb}^{2+}$ treatments as compared to the control (see Supplementary Figures 1-4).

3.4. Multilineage Capability of All MSCs Cell Lines after Exposure to $\mathrm{Pb}^{2+}$. We investigated the potential of BM-MSCs, SCDs, DPSCs, and PDLs to differentiate into osteogenic, chondrogenic, and adipogenic lineages at various concentrations of $\mathrm{Pb}^{2+}$ (Figure 3). Osteogenic differentiation was confirmed by the detection of the silver stained mineralized matrix in the control samples. While SCDs, DPSCs, and PDLs showed a weak deposition of calcium in the mineralized matrix only at the pretreatment with $160 \mu \mathrm{M}$ of $\mathrm{Pb}^{2+}$, BM-MSCs preexposed to $\mathrm{Pb}^{2+}$ concentration of $40 \mu \mathrm{M}$ have started to show a similar observation (Figure 3 ). Chondrogenic differentiation was detected by the presence of proteoglycans stained with alcian blue at day 21 in BM-MSCs, SCDs, PDLs, and DPSCs.

No significant differences were noticed between the control and pretreatment with $\mathrm{Pb}^{2+}$ in all MSC sources. Adipogenic differentiation was confirmed in BM-MSCs, SCDs, DPSCs, and PDLs by the accumulation of neutral lipid vacuoles indicated by the Oil Red $\mathrm{O}$ stain as shown in control (Figure 3). We discovered that for dental derived stem cells, the lipid vacuoles were observed until the highest concentration, although for BM-MSCs the neutral lipid droplet showed less accumulation of lipid vacuoles of cells exposed to 80 up to $160 \mu \mathrm{M}$.

3.5. Gene Expression Profile of Stem Cells upon Exposure to $\mathrm{Pb}^{2+}$. We further analysed the effect of $\mathrm{Pb}^{2+}$ on MSCs through gene expression analysis. The gene analysis was only 
TABLE 1: Changes in trypan blue dye exclusion assay, 3-(4,5-dimethylthiazol-2-yl)-2-,5-diphenyltetrazolium bromide (MTT) assay, and lactate dehydrogenase leakage $(\mathrm{LDH})$ rate at various $\mathrm{Pb}^{2+}$ concentrations (mean $\pm \mathrm{SD}$ ).

\begin{tabular}{lccccccc}
\hline Index & Sample source & Control & $10 \mu \mathrm{M}$ & $20 \mu \mathrm{M}$ & $40 \mu \mathrm{M}$ & $80 \mu \mathrm{M}$ & $160 \mu \mathrm{M}$ \\
\hline & BM-MSCs & $3.13 \pm 0.07$ & $2.85 \pm 0.72$ & $1.31 \pm 0.33$ & $1.21 \pm 0.34$ & $1.08 \pm 0.69$ & $0.65 \pm 0.04$ \\
Trypan blue (in millions) & SCDs & $4.54 \pm 0.66$ & $4.25 \pm 0.65$ & $4.25 \pm 0.42$ & $4.21 \pm 0.67$ & $3.90 \pm 0.60$ & $3.45 \pm 0.65$ \\
& PDLs & $9.04 \pm 0.11$ & $8.88 \pm 0.67$ & $8.36 \pm 0.91$ & $8.31 \pm 0.09$ & $7.90 \pm 0.55$ & $7.08 \pm 0.82$ \\
& DPSCs & $5.33 \pm 0.95$ & $4.65 \pm 0.53$ & $4.44 \pm 0.51$ & $4.19 \pm 0.91$ & $4.07 \pm 0.56$ & $3.51 \pm 0.67$ \\
\hline & BM-MSCs & $1.07 \pm 0.06$ & $1.02 \pm 0.02$ & $0.98 \pm 0.14$ & $0.92 \pm 0.05$ & $0.82 \pm 0.31$ & $0.24 \pm 0.03$ \\
MTT & SCDs & $1.14 \pm 0.03$ & $1.09 \pm 0.15$ & $0.97 \pm 0.25$ & $0.94 \pm 0.02$ & $0.89 \pm 0.21$ & $0.87 \pm 0.04$ \\
& PDLs & $1.24 \pm 0.36$ & $1.12 \pm 0.66$ & $1.10 \pm 0.58$ & $0.98 \pm 0.29$ & $0.80 \pm 0.31$ & $0.74 \pm 1.45$ \\
& DPSCs & $1.47 \pm 0.74$ & $1.27 \pm 0.26$ & $0.10 \pm 0.23$ & $0.80 \pm 0.84$ & $0.69 \pm 0.08$ & $0.55 \pm 0.06$ \\
\hline \multirow{5}{*}{ LDH (\% of control) } & BM-MSCs & 100 & $120.45 \pm 1.45$ & $135.52 \pm 1.58$ & $146.48 \pm 1.73$ & $158.60 \pm 1.46$ & $164.42 \pm 1.95$ \\
& SCDs & 100 & $124.84 \pm 1.86$ & $134.15 \pm 1.42$ & $141.53 \pm 1.36$ & $149.59 \pm 1.72$ & $154.28 \pm 1.31$ \\
& PDLs & 100 & $116.35 \pm 1.34$ & $124.74 \pm 2.04$ & $136.84 \pm 1.98$ & $146.15 \pm 2.14$ & $158.26 \pm 2.3$ \\
& DPSCs & 100 & $124.52 \pm 1.81$ & $136.43 \pm 1.47$ & $142.55 \pm 2.26$ & $149.46 \pm 2.41$ & $153.98 \pm 2.32$ \\
\hline
\end{tabular}

carried out with cell lines treated with $160 \mu \mathrm{M} \mathrm{Pb}^{2+}$ after taking into consideration that other concentrations of $\mathrm{Pb}^{2+}$ did not significantly impact the proliferation and differentiation of MSCs. Firstly, the effect of $\mathrm{Pb}^{2+}$ on the stemness and self-renewal (markers such as Nanog, Rex land Oct 4) were evaluated. Rex 1 and Oct 4 were uniformly maintained among the control and treated samples for all four sources of MSCs except for Nanog which was downregulated in PDLs compared to the other cell lines. Next, the effect of $\mathrm{Pb}^{2+}$ on MSCs in terms of lineage specificities was assessed. We observed a sharp decrease in expression of HNF- $4 \alpha$ and SOX 17 , early endoderm genes in the cells treated with $\mathrm{Pb}^{2+}$ from BM-MSCs. Nevertheless, the expression of HNF- $4 \alpha$ and SOX 17 were similar in control and $\mathrm{Pb}^{2+}$ treated SCDs, DPSCs, and PDLs. In $\mathrm{Pb}^{2+}$ treated samples, the expression of SOX 1 and NURR1, in early ectoderm markers, was considerably downregulated in BM-MSCs, while the expression of KRT15 was relatively stable among all sources. We also looked for signs of transformation in cells treated with $\mathrm{Pb}^{2+}$. We found that the expressions ERCC3, XRCC14, and RAD 51 remain unchanged in control and $\mathrm{Pb}^{2+}$ treated samples (Figures 4 and $5)$.

\section{Discussion}

For centuries, $\mathrm{Pb}^{2+}$ poisoning had posed a serious environment threat for human health in all societies [29]. Children have been more vulnerable to $\mathrm{Pb}^{2+}$ exposure than adults for many potential reasons, including their exposure to $\mathrm{Pb}^{2+}$, favoured by the habit of eating unhealthy food coupled with the evidence that a child's intestine absorbs $\mathrm{Pb}^{2+}$ much faster than that of an adult [30]. Among the detrimental effects of $\mathrm{Pb}^{2+}$ are the disruption of the peripheral and central nervous system [31, 32], blood, and skeletal systems $[33,34] . \mathrm{Pb}^{2+}$ is stored mainly in the skeletal systems and reenters the blood circulation depending on bone turnover rates, which in turn depend on the type of bone (compact or trabecular) as well as on physiological and pathological conditions that affect the bone turnover rates $[35,36]$. Given the multifaceted effects of $\mathrm{Pb}^{2+}$, it is important that we have a strong and continuous dataset for a better understanding of $\mathrm{Pb}^{2+}$ toxicity. Conventionally, laboratory animal-based systems have been used for toxicology studies, but conclusions based on animal testing raise questions due to numerous species-specific differences [37]. Alternatives such as whole embryo cultures and cellular models using primary or immortal cell lines have been developed. In this regard, stem cells from a dental origin could be an ideal cell source for $\mathrm{Pb}^{2+}$ screening and testing. Apart from noninvasive procedures in obtaining the cells, dental enamel is known to accumulate high amounts of $\mathrm{Pb}^{2+}$ on its surface $[13,38-43]$. This artificial localization of $\mathrm{Pb}^{2+}$ turns dental enamel into a potentially interesting marker of exposure to $\mathrm{Pb}^{2+}$. Indeed, some studies have revealed that there is a relationship between the $\mathrm{Pb}^{2+}$ in surface enamel $(\mathrm{Pb}$-enamel) and environmental lead exposure in permanent teeth [38-42] and in primary teeth $[13,43]$.

In this investigation, we have shown that $\mathrm{Pb}^{2+}$ exposure inhibited adhesion with the highest being in BM-MSCs followed by SCDs, DPSCs, and PDLs as well as it increased the biological aging of the cells in a dose-dependent manner. Surprisingly, we noticed that dental derived stem cells are resistant to $\mathrm{Pb}^{2+}$ compared to BM-MSCs. One of the reasons is due to dissimilarities in age and gender of the donors. It should be noted that proliferation of stem cells gradually decreases as the age increases [44, 45]. But, at the mechanistic level, $\mathrm{Pb}^{2+}$ and ionic calcium $\left(\mathrm{Ca}^{2+}\right)$ have a similar mechanism in entering and leaving the bone. Further, $\mathrm{Pb}^{2+}$ also follows the movement of $\mathrm{Ca}^{2+}$ in the body as it utilises the same ion transporter as calcium, acting like a competitive inhibitor [46]. The ion transporter and binding site of $\mathrm{Ca}^{2+}$ will recognize $\mathrm{Pb}^{2+}$ instead of $\mathrm{Ca}^{2+}$ and $\mathrm{Pb}^{2+}$ is released from the bone cells, along with $\mathrm{Ca}^{2+}$, when the bone is demineralised (as reviewed by [47]). But we postulate that the demineralisation process is slow in teeth allowing the cells of dental origin to adapt for more resistance to $\mathrm{Pb}^{2+}$ toxicity. In this study we identified that the concentration of $\mathrm{Pb}^{2+}(40$ to $160 \mu \mathrm{M})$ suppressed the proliferation of stem cells rather 
TABLE 2: Immunophenotype analysis of bone marrow mesenchymal stem cells (BM-MSCs), dental permanent stem cells (DPSCs), dental deciduous stem cells (SCDs), and periodontal ligament stem cells (PDLs), respectively, cultured before and after treatment of $\mathrm{Pb}^{2+}$. $\mathrm{BM}^{-}$ MSCs were tested against human antigens CD34, CD44, CD45, CD73, CD166, and HLA-DR. 7-AAD was used to check the viability of the cells. The results represent average of 3 independent culture replicates.

(a)

\begin{tabular}{lcccccccc}
\hline BM-MSCs & 7AAD & HLA-DR & CD34 & CD45 & CD44 & CD73 & CD90 & CD166 \\
\hline Control & $9.78 \%$ & $20.22 \%$ & $20.25 \%$ & $21.81 \%$ & $77.04 \%$ & $74.99 \%$ & $72.78 \%$ & $51.50 \%$ \\
$10 \mu \mathrm{M}$ & $2.60 \%$ & $17.32 \%$ & $18.74 \%$ & $18.34 \%$ & $80.86 \%$ & $74.48 \%$ & $70.36 \%$ & $46.44 \%$ \\
$20 \mu \mathrm{M}$ & $7.60 \%$ & $25.24 \%$ & $25.90 \%$ & $23.34 \%$ & $74.48 \%$ & $67.78 \%$ & $62.44 \%$ & $54.72 \%$ \\
$40 \mu \mathrm{M}$ & $6.24 \%$ & $17.94 \%$ & $16.06 \%$ & $18.66 \%$ & $82.24 \%$ & $77.70 \%$ & $68.99 \%$ & $57.22 \%$ \\
$80 \mu \mathrm{M}$ & $7.40 \%$ & $20.89 \%$ & $22.57 \%$ & $21.54 \%$ & $73.09 \%$ & $74.27 \%$ & $66.16 \%$ & $67.62 \%$ \\
$160 \mu \mathrm{M}$ & $10.78 \%$ & $24.89 \%$ & $27.07 \%$ & $26.32 \%$ & $70.62 \%$ & $68.45 \%$ & $52.87 \%$ & $68.19 \%$ \\
\hline
\end{tabular}

(b)

\begin{tabular}{lcccccccc}
\hline DPSCs & 7AAD & HLA-DR & CD34 & CD45 & CD44 & CD73 & CD90 & CD166 \\
\hline Control & $2.82 \%$ & $24.21 \%$ & $23.50 \%$ & $23.94 \%$ & $74.62 \%$ & $76.49 \%$ & $48.87 \%$ & $53.03 \%$ \\
$10 \mu \mathrm{M}$ & $3.86 \%$ & $20.11 \%$ & $19.80 \%$ & $20.16 \%$ & $80.58 \%$ & $80.72 \%$ & $66.41 \%$ & $69.32 \%$ \\
$20 \mu \mathrm{M}$ & $6.59 \%$ & $30 \%$ & $27.30 \%$ & $28.49 \%$ & $60.33 \%$ & $74.84 \%$ & $65.98 \%$ & $71.66 \%$ \\
$40 \mu \mathrm{M}$ & $6.03 \%$ & $30.64 \%$ & $31.68 \%$ & $31.32 \%$ & $69.44 \%$ & $66.48 \%$ & $65.23 \%$ & $67.20 \%$ \\
$80 \mu \mathrm{M}$ & $4.82 \%$ & $33.42 \%$ & $31.90 \%$ & $32.63 \%$ & $78.31 \%$ & $69.22 \%$ & $70.07 \%$ & $66.02 \%$ \\
$160 \mu \mathrm{M}$ & $4.73 \%$ & 31.04 & $32.05 \%$ & $31.87 \%$ & $66.45 \%$ & $67.93 \%$ & $60.14 \%$ & $68.05 \%$ \\
\hline
\end{tabular}

(c)

\begin{tabular}{lcccccccc}
\hline SCDs & 7AAD & HLA-DR & CD34 & CD45 & CD44 & CD73 & CD90 & CD166 \\
\hline Control & $3.28 \%$ & $19.82 \%$ & $21.88 \%$ & $21.71 \%$ & $74.75 \%$ & $75.40 \%$ & $68.23 \%$ & $47.84 \%$ \\
$10 \mu \mathrm{M}$ & $3.57 \%$ & $21.88 \%$ & $28.57 \%$ & $27.57 \%$ & $55.71 \%$ & $69.13 \%$ & $59.82 \%$ & $53.25 \%$ \\
$20 \mu \mathrm{M}$ & $49.95 \%$ & $30.18 \%$ & $34.44 \%$ & $30.51 \%$ & $70.16 \%$ & $72.23 \%$ & $75.66 \%$ & $41.45 \%$ \\
$40 \mu \mathrm{M}$ & $45.16 \%$ & $43.36 \%$ & $42.06 \%$ & $42.06 \%$ & $60.97 \%$ & $65.94 \%$ & $62.75 \%$ & $41.83 \%$ \\
$80 \mu \mathrm{M}$ & $43.90 \%$ & $50.52 \%$ & $49.71 \%$ & $49.60 \%$ & $36.82 \%$ & $48.71 \%$ & $52.05 \%$ & $30.39 \%$ \\
$160 \mu \mathrm{M}$ & $47.17 \%$ & $44.86 \%$ & $45.07 \%$ & $45.20 \%$ & $55.93 \%$ & $63.16 \%$ & $60.94 \%$ & $41.94 \%$ \\
\hline
\end{tabular}

(d)

\begin{tabular}{|c|c|c|c|c|c|c|c|c|}
\hline PDLs & 7AAD & HLA-DR & CD34 & CD45 & CD44 & CD73 & CD90 & CD166 \\
\hline Control & $7.74 \%$ & $15.60 \%$ & $15.57 \%$ & $15.32 \%$ & $78.33 \%$ & $80.23 \%$ & $77.15 \%$ & $44.02 \%$ \\
\hline $10 \mu \mathrm{M}$ & $2.66 \%$ & $23.34 \%$ & $23.23 \%$ & $24.05 \%$ & $72.54 \%$ & $73.31 \%$ & $71.62 \%$ & $53.57 \%$ \\
\hline $20 \mu \mathrm{M}$ & $3.48 \%$ & $28.70 \%$ & $28.24 \%$ & $29.23 \%$ & $66.42 \%$ & $69.62 \%$ & $62.05 \%$ & $34.90 \%$ \\
\hline $40 \mu \mathrm{M}$ & $3.01 \%$ & $30.84 \%$ & $31.68 \%$ & $31.70 \%$ & $62.60 \%$ & $64.96 \%$ & $58.66 \%$ & $34.13 \%$ \\
\hline $80 \mu \mathrm{M}$ & $5.79 \%$ & $31.34 \%$ & $33.75 \%$ & $34.65 \%$ & $60.92 \%$ & $60.24 \%$ & $58.84 \%$ & $42.02 \%$ \\
\hline $160 \mu \mathrm{M}$ & $7.65 \%$ & $39.17 \%$ & $38.43 \%$ & $38.99 \%$ & $55.80 \%$ & $58.91 \%$ & $70.07 \%$ & $45.62 \%$ \\
\hline
\end{tabular}

than inducing cell death. One possible explanation is that platelets are present in significant amounts in stem cells or bone marrow mononuclear cell cultures $[48,49]$ and $\mathrm{Pb}^{2+}$ is thought to influence platelets or lysate-based platelets by regulating the levels of growth chemotactic factors [50]. Thus, we speculate that $\mathrm{Pb}^{2+}$ inhibits growth factors related to the proliferation of stem cells resulting in slow growth of cells.

Next, we demonstrated that all four sources of MSCs were capable of differentiating into osteoblast, chrondocytes, and adipocytes in control samples. All four levels of $\mathrm{Pb}^{2+}$ exposed to MSCs cultured in an osteogenesis medium showed a reduction in osteogenesis differentiation capacity but a higher prevalence was observed in BM-MSCs.
$\mathrm{Pb}^{2+}$ has been shown in various tissues to block calcium signalling and inhibit $\mathrm{Ca}^{2+} /$ phosphorylation and activation. There are also reports suggesting that $\mathrm{Pb}^{2+}$ suppressed the expression of osteogenic genes such as osteocalcin, alkaline phosphatase, and type I collagen [51].

In conclusion, we suggest that $\mathrm{Pb}^{2+}$ disturbed the osteogenic pathways, inhibiting the osteoblast differentiation. On the other hand, the results we obtained showed that the chondrogenesis was not greatly affected. $[52,53]$.

$\mathrm{Pb}^{2+}$ was found to induce chondogenesis in the presence of the transforming growth factor- $\beta$ (TGF- $\beta$ ) and bone morphogenetic proteins (BMP) in MSCs [54-57]. 


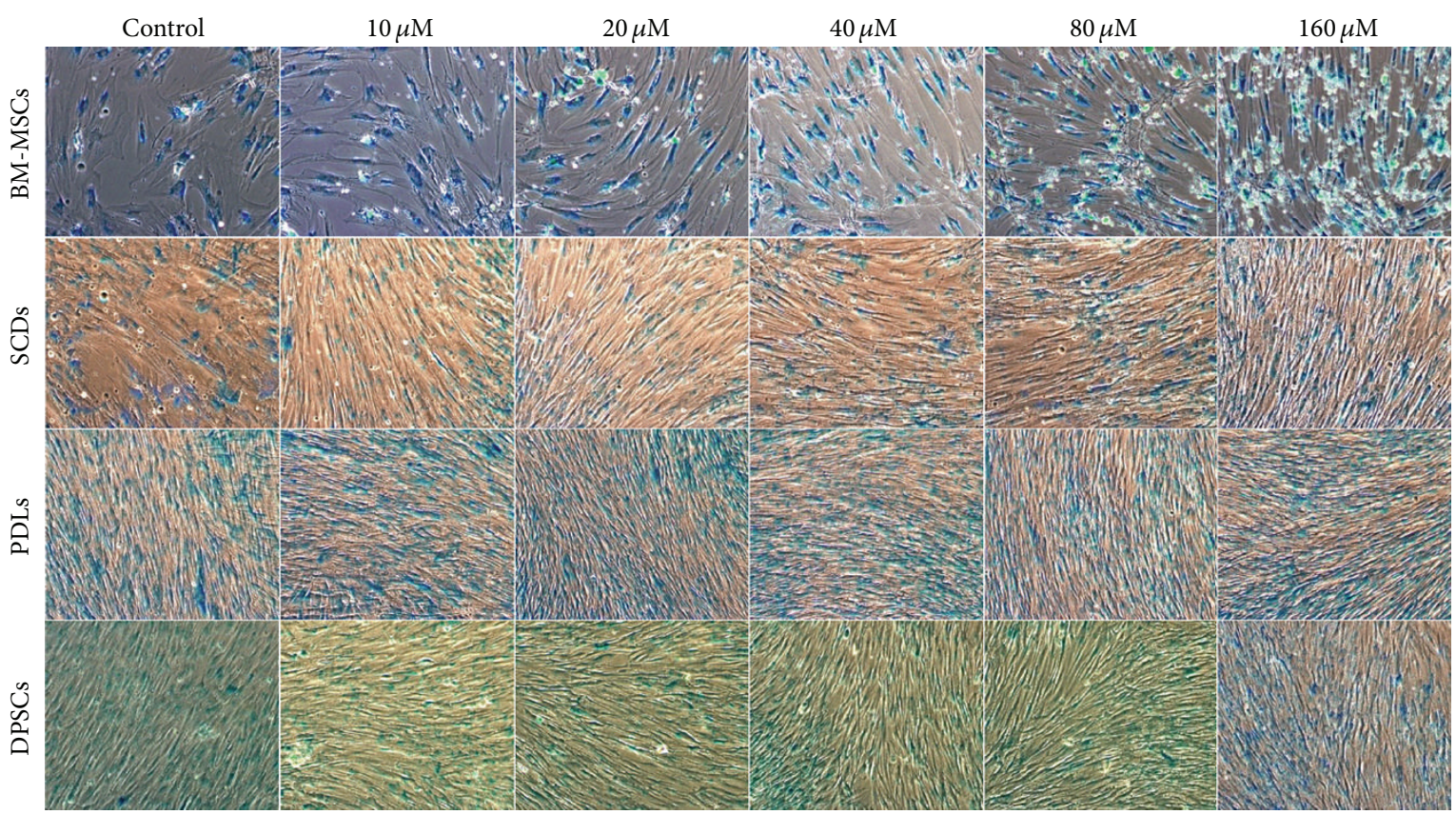

(a)

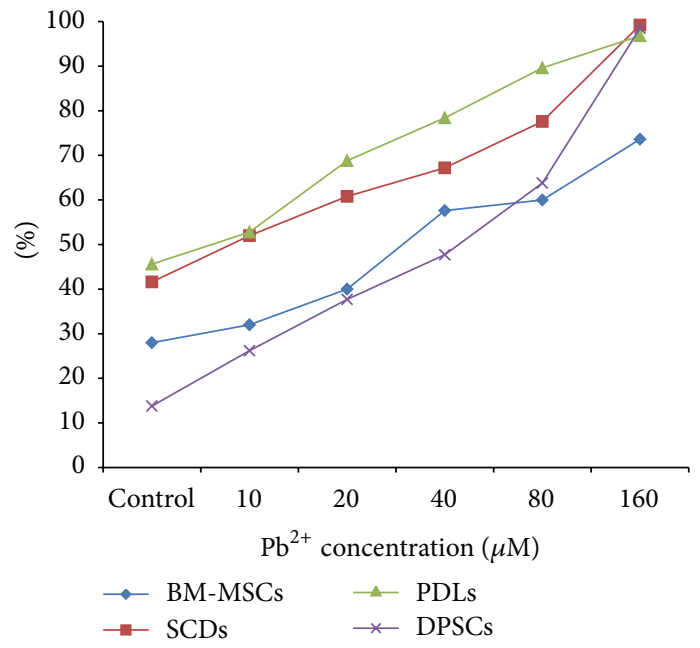

(b)

Figure 2: (a) Conventional qualitative SA- $\beta$-gal assay by X-gal staining of bone marrow mesenchymal stem cells (BM-MSCs), deciduous (SCDs), permanent (DPSCs), and periodontal ligament (PDLs) upon exposure to various concentrations of $\mathrm{Pb}^{2+}$. $\mathrm{A}_{\text {locally region of }}$ senescence cell is shown; (b) quantification of percentage (\%) of SA- $\beta$-gal positive cells exposed to various concentrations of $\mathrm{Pb}^{2+}$. In all experiments, the results represent average of five culture replicates with standard deviation and a representative photomicrograph was given for each experiment.

The expression of CD166 was affected in $\mathrm{Pb}^{2+}$ exposed SCDs. This cell surface antigen is a known putative cancer stem cell marker derived in colorectal cancer [58]. It was speculated that the loss of expression of these markers contributed to metastasis. We suggest that $\mathrm{Pb}^{2+}$ did not significantly affect the rest of the cell surface antigen markers. This is because the target area for $\mathrm{Pb}^{2+}$ is in the chromatin and DNA of the cells which are located in the nucleus. Studies have been reported that $\mathrm{Pb}^{2+}$ interacts with histone protein in DNA and affects its integrity by forming cross links and eventually forms soluble complexes [59]. These complexes in turn may decrease the fidelity of DNA [60] and inhibits DNA and RNA synthesis, the process that introduces $\mathrm{Pb}^{2+}$ toxicity at the chromatin level [59]. Nevertheless, $\mathrm{Pb}^{2+}$ on cell surfaces is reported to increase $\mathrm{B}$ cell surface expression of murine MHC class II molecules [61].

Our results on gene expressions show that the gene repair enzyme did not significantly change the control and $\mathrm{Pb}^{2+}$ treated samples for all four MSC sources. This finding supports an earlier study stating that stem cells display an 

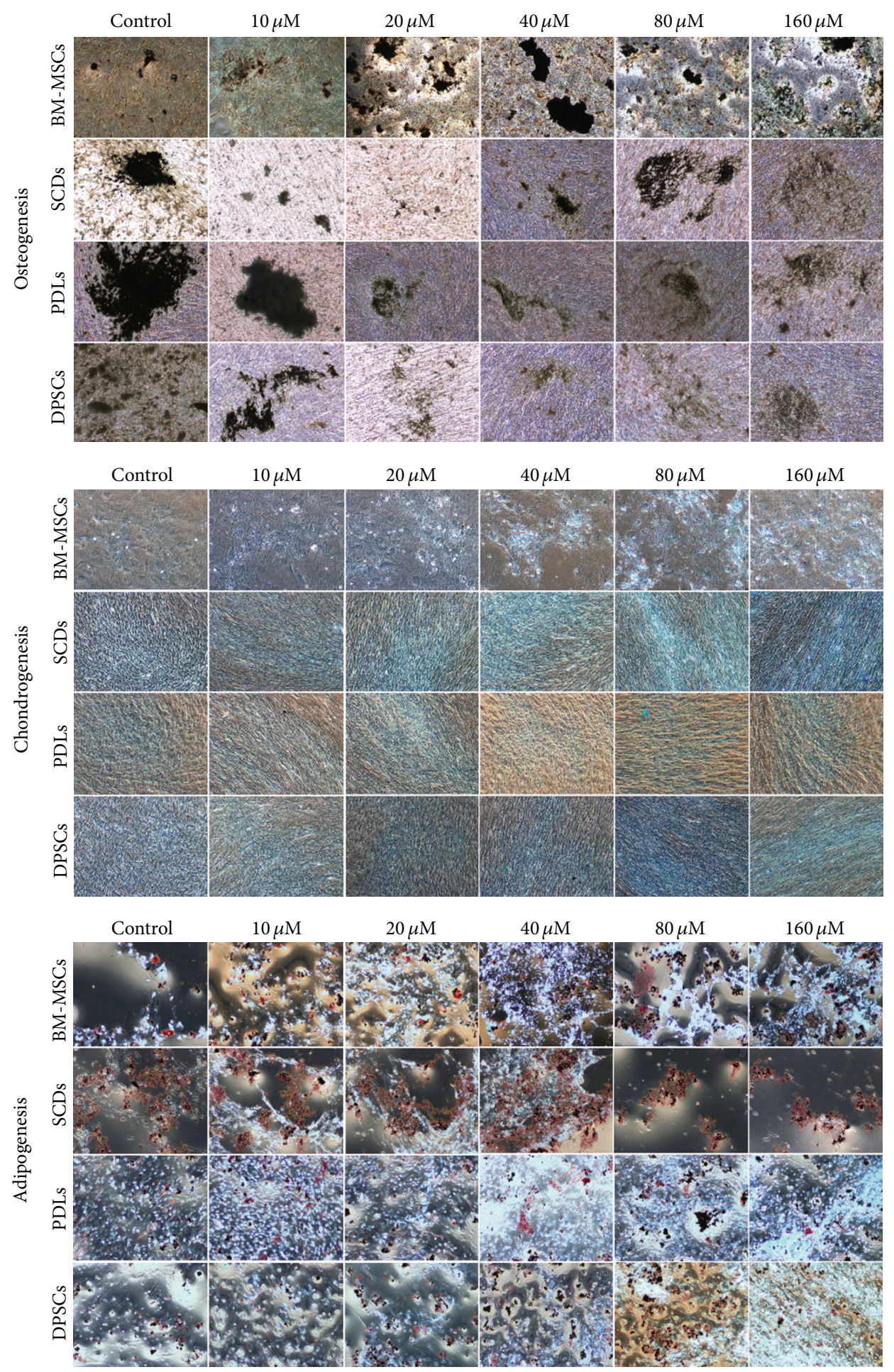

FIGURE 3: In vitro differential potentiality of bone marrow stem cells (BM-MSCs), deciduous stem cells (SCDs), periodontal ligament stem cells (PDLs), and permanent stem cells (DPSCs) in presence of various concentrations of $\mathrm{Pb}^{2+}$. Osteogenesis was confirmed by mineralized matrix deposition stained with von Kossa staining at day 21. Adipogenesis was detected by neutral oil droplet formation stained with Oil Red $\mathrm{O}$ at day 21. Chondogenesis was detected by the presence of proteoglycans stained with alcian blue dye at day 21 . The results represent average of 3 independent culture replicates. A representative photomicrograph was given for each experiment. 

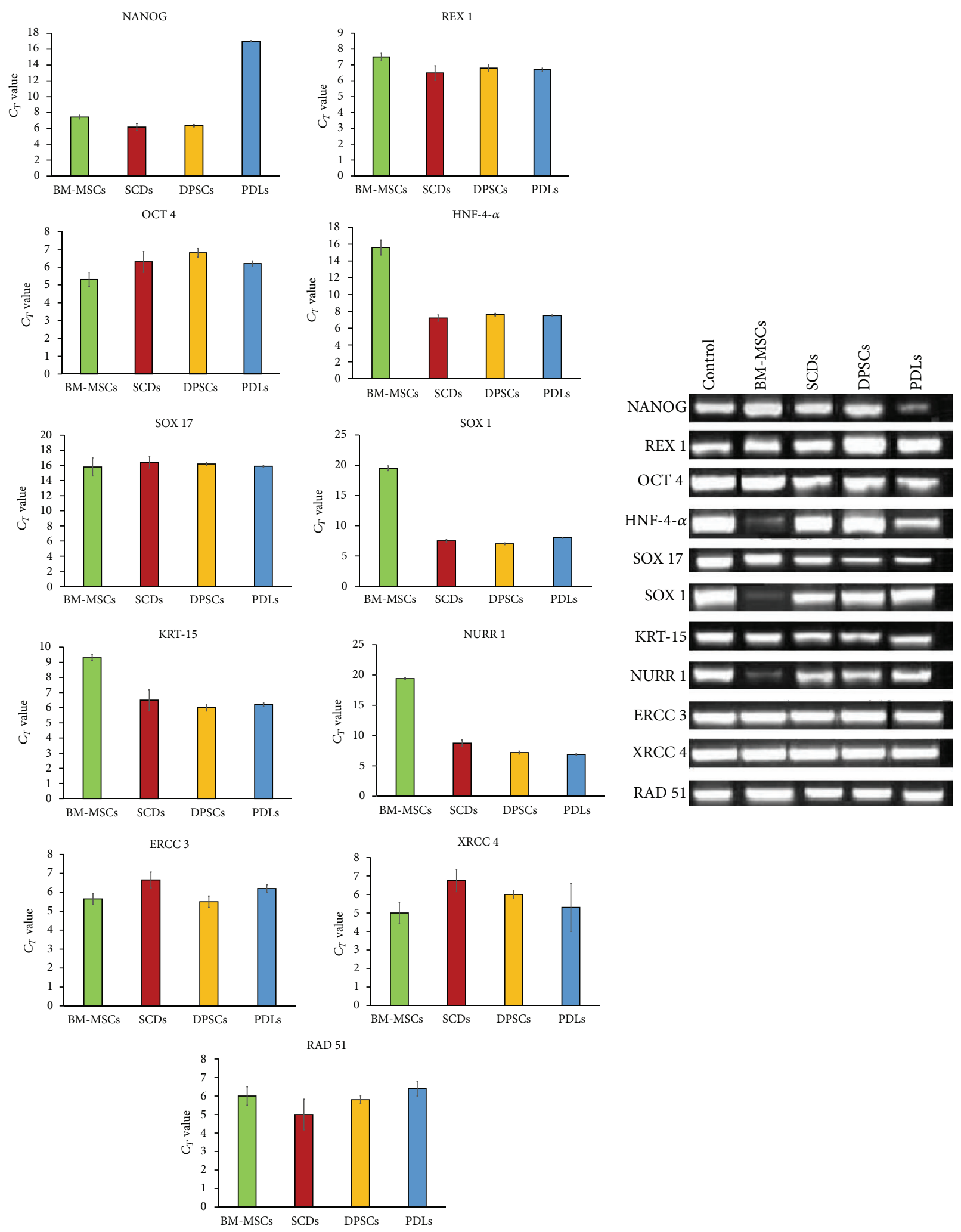

(a)

(b)

FIGURE 4: ((a) and (b)) Gene expression analysis of bone marrow stem cells (BM-MSCs), deciduous stem cells (SCDs), periodontal ligament stem cells (PDLs), and permanent stem cells (DPSCs) for control and after treatment of $\mathrm{Pb}^{2+}$ at $160 \mu \mathrm{mol}$. BM-MSCs, SCDs, DPSCs, and PDLs were tested against gene repair enzyme (ERCC3, XRCC14, RAD 51), stemness and self-renewal (Nanog, Rex 1, Oct 4), endoderm lineage (HNF-4 $\alpha$, SOX 17), and ectoderm lineage (SOX 1, KRT-15, NURR1). The lower a cycle threshold $\left(C_{T}\right)$ value is, the more copies are present in the specific sample. Values are presented after being normalized to $18 \mathrm{~s}$ mRNA levels. The average of 3 replicates is displayed. 

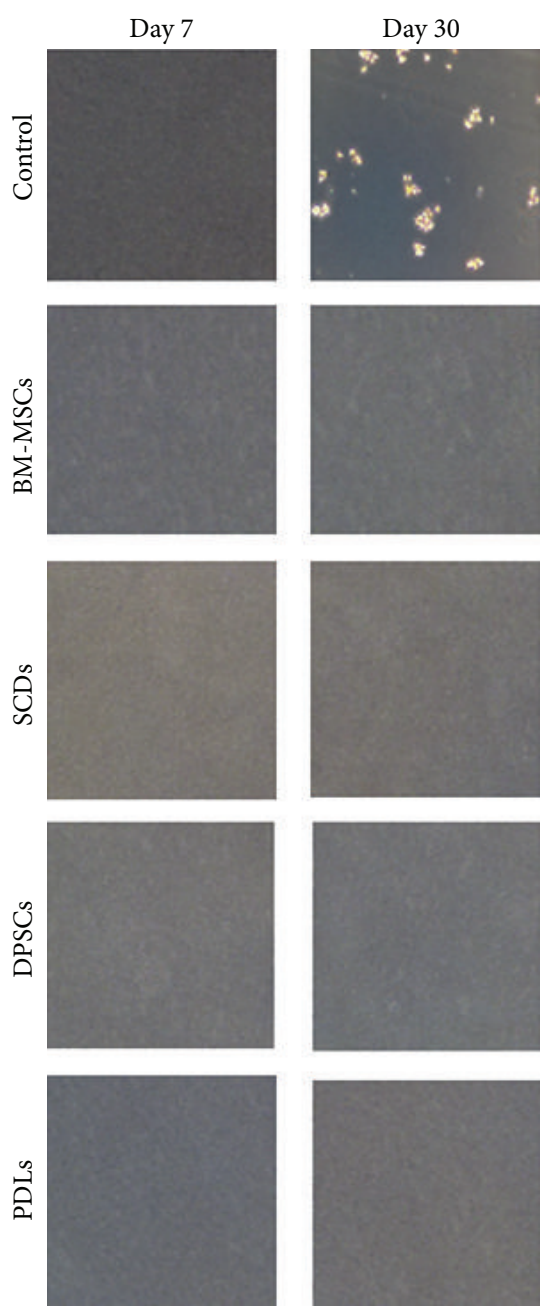

FIGURE 5: Soft agar assay of bone marrow stem cells (BM-MSCs), deciduous stem cells (SCDs), periodontal ligament stem cells (PDLs), and permanent stem cells (DPSCs) with HeLa cells as control after treatment of $\mathrm{Pb}^{2+}$ at $160 \mu \mathrm{M}$. Phase contrast microscope; 10x magnification of BM-MSCs, SCDs, PDLs, and DPSCs in presence of various concentrations of $\mathrm{Pb}^{2+}$.

enhanced capacity to repair multiple forms of DNA damage including $\mathrm{H}_{2} \mathrm{O}_{2}, \mathrm{UV}-\mathrm{C}$, and ionizing radiation [62].

Recent studies have shown that a chronic low level of $\mathrm{Pb}^{2+}$ exposure may inhibit neurogenesis especially in the hippocampal formation and affect the differentiation/maturation of the newly generated neurons [63-65].

It has been reported that the heavy metals including $\mathrm{Pb}^{2+}$ interferes or inhibits gamma-aminobutyric acid (GABA), an inhibitory neurotransmitter binding to GABA receptors, a member of the ligand-gated ion channel super family [66]. Likewise, we hypothesize that activation of a similar pathway induced by GABA-mediated inhibition leads to selective silencing of neuronal markers such as SOX 1 and NURR1 in the present study. We observed a sharp decreased expression of HNF- $4 \alpha$ in the cells treated with $\mathrm{Pb}^{2+}$ from BM-MSCs. In contrast, the expression of HNF- $4 \alpha$, a hepatic marker, had somewhat similar effects on SCDs, DPSCs, and PDLs. We observed that BM-MSCs have lower expression of HNF- $4 \alpha$ marker compared to the other dental-derived MSCs sources. This is possibly due to the effect of $\mathrm{Pb}^{2+}$ displacing metal ions from proteins by altering the homeostasis of metals which could explain the effect of $\mathrm{Pb}^{2+}$ on gene expression. Our results are in agreement with the report demonstrating the regulation of $\mathrm{Pb}^{2+}$ in hepatocytes [67], indicating a hepatotoxic potential of $\mathrm{Pb}^{2+}$.

\section{Conclusions}

We propose that the dental derived stem cells especially PDLs are an ideal source for in vitro heavy metal screening since it can withstand the toxicity of $\mathrm{Pb}^{2+}$ better than the other cell lines making it as one of the final frontiers to evaluate the extremisms of $\mathrm{Pb}^{2+}$ toxicity. Nevertheless, few factors need to be taken into consideration to avoid misinterpretation of data: (a) establishment of a good quality and quantity of cell lines is crucial to get a legitimate endpoint of heavy metal toxicity studies; (b) exposure of heavy metals should be prolonged to cover subchronic or chronic effects; (c) a combined battery of experiments covering physiology and biochemistry should be run concurrently to understand the synergic and agonistic effects of heavy metals.

\section{Conflict of Interests}

The authors declare that there is no conflict of interests regarding the publication of the paper.

\section{Acknowledgments}

This work is part of a research collaboration between the Faculty of Dentistry University of Malaya and Hygieia Innovation Sdn Bhd. This work is supported by the University of Malaya High Impact Research Grant (UM.C/625/1/HIR/ 065).

\section{References}

[1] H. Needleman, "Lead poisoning," Annual Review of Medicine, vol. 55, pp. 209-222, 2004.

[2] T. W. Clarkson, "Effects-general principles underlying the toxic action of metals," in Handbook on the Toxicology of Metals, L. Friberg, G. F. Nordberg, and V. B. Vouk, Eds., pp. 128-148, Elsevier, Amsterdam, The Netherlands, 1990.

[3] L. R. Goldman, "Children-unique and vulnerable. Environmental risks facing children and recommendations for response," Environmental Health Perspectives, vol. 103, no. 6, pp. 13-18, 1995.

[4] I. M. Shapiro, B. Dobkin, O. C. Tuncay, and H. L. Needleman, "Lead levels in dentine and circumpulpal dentine of deciduous teeth of normal and lead poisoned children," Clinica Chimica Acta, vol. 46, no. 2, pp. 119-123, 1973.

[5] H. T. Delves and M. J. Campbell, "Identification and apportionment of sources of lead in human tissue," Environmental Geochemistry and Health, vol. 15, no. 2-3, pp. 75-84, 1993.

[6] H. L. Needleman and I. M. Shapiro, "Dentine lead levels in asymptomatic Phildelphia school children: subclinical exposure 
in high and low risk groups," Environmental Health Perspectives, vol. 7, pp. 27-31, 1974.

[7] A. Al-Haddad, F. Al-Saleh, and F. Al-Mahroos, "Levels of cadmium, copper and iron in deciduous teeth of children living in Bahrain," International Journal of Environmental Health Research, vol. 9, no. 4, pp. 261-268, 1999.

[8] J. Appleton, K. M. Lee, K. Sawicka Kapusta, M. Damek, and M. Cooke, "The heavy metal content of the teeth of the bank vole (Clethrionomys glareolus) as an exposure marker of environmental pollution in Poland," Environmental Pollution, vol. 110, no. 3, pp. 441-449, 2000.

[9] I. Baranowska, L. Barchański, M. Bk, B. Smolec, and Z. Mzyk, "X-ray fluorescence spectrometry in multielemental analysis of hair and teeth," Polish Journal of Environmental Studies, vol. 13, no. 6, pp. 639-646, 2004.

[10] M. L. Carvalho, C. Casaca, T. Pinheiro, J. P. Marques, P. Chevallier, and A. S. Cunha, "Analysis of human teeth and bones from the chalcolithic period by X-ray spectrometry," Nuclear Instruments and Methods in Physics Research B, vol. 168, no. 4, pp. 559-565, 2000.

[11] J. Gdula-Argasińska, J. Appleton, K. Sawicka-Kapusta, and B. Spence, "Further investigation of the heavy metal content of the teeth of the bank vole as an exposure indicator of environmental pollution in Poland," Environmental Pollution, vol. 131, no. 1, pp. 71-79, 2004.

[12] R. F. Gerlach, D. B. Toledo, P. D. Novaes, J. Merzel, and S. R. P. Line, "The effect of lead on the eruption rates of incisor teeth in rats," Archives of Oral Biology, vol. 45, no. 11, pp. 951-955, 2000.

[13] V. E. Gomes, M. D. L. R. de Sousa, F. Barbosa Jr. et al., "In vivo studies on lead content of deciduous teeth superficial enamel of preschool children," Science of the Total Environment, vol. 320, no. 1, pp. 25-35, 2004.

[14] B. Nowak and J. Chmielnicka, "Relationship of lead and cadmium to essential elements in hair, teeth, and nails of environmentally exposed people," Ecotoxicology and Environmental Safety, vol. 46, no. 3, pp. 265-274, 2000.

[15] M. L. Sargentini-Maier, R. M. Frank, M. J. Leroy, and J. C. Turlot, "A method of lead determination in human teeth by energy dispersive X-ray fluorescence (EDXRF)," Journal of Trace Elements and Electrolytes in Health and Disease, vol. 2, no. 4, pp. 221-226, 1988.

[16] I. M. Sharon, "The significance of teeth in pollution detection," Perspectives in Biology and Medicine, vol. 32, no. 1, pp. 124-131, 1988.

[17] R. Lansdown, "Lead, intelligence, attainment and behavior," in The Lead Debate: The Environment, Toxicology and Child Health, R. Lansdown and W. Yule, Eds., pp. 235-270, Croom Helm, London, UK, 1986.

[18] J. E. Fergusson and N. G. Purchase, "The analysis and levels of lead in human teeth: a review," Environmental Pollution, vol. 46, no. 1, pp. 11-44, 1987.

[19] S. J. Pocock, M. Smith, and P. Baghurst, "Environmental lead and children's intelligence: a systematic review of the epidemiological evidence," The British Medical Journal, vol. 309, no. 6963, pp. 1189-1197, 1994.

[20] K. R. Mahaffey, J. McKinney, and J. R. Reigart, "Lead and compounds," in Environmental Toxicants Human Exposure and Their Health Effects, M. Lippmann, Ed., pp. 360-391, Van Nostrand Reinhold, New York, NY, USA, 1992.

[21] Y. Hayama, "Effect of heavy metal ions on the cells derived from human periodontal ligament. Effects of $\mathrm{Pb}$ and $\mathrm{Cd}$," The Journal of the Kanagawa Odontological Society, vol. 24, no. 4, pp. 671691, 1990.

[22] H. M. Tvinnereim, R. Eide, and T. Riise, "Heavy metals in human primary teeth: some factors influencing the metal concentrations," Science of the Total Environment, vol. 255, no. $1-3$, pp. 21-27, 2000.

[23] S. Thaweboon, P. Chunhabundit, R. Surarit, S. Swasdison, and P. Suppukpatna, "Effects of lead on the proliferation, protein production, and osteocalcin secretion of human dental pulp cells in vitro," The Southeast Asian Journal of Tropical Medicine and Public Health, vol. 33, no. 3, pp. 654-661, 2002.

[24] R. Pal, M. Hanwate, M. Jan, and S. Totey, "Phenotypic and functional comparison of optimum culture conditions for upscaling of bone marrow-derived mesenchymal stem cells," Journal of Tissue Engineering and Regenerative Medicine, vol. 3, no. 3, pp. 163-174, 2009.

[25] V. Govindasamy, V. S. Ronald, S. Totey et al., "Micromanipulation of culture niche permits long-term expansion of dental pulp stem cells-an economic and commercial angle," In Vitro Cellular and Developmental Biology, vol. 46, no. 9, pp. 764-773, 2010.

[26] X. Shen, K. Lee, and R. König, "Effects of heavy metal ions on resting and antigen-activated CD4+ T cells," Toxicology, vol. 169, no. 1, pp. 67-80, 2001.

[27] L. Braydich-Stolle, S. Hussain, J. J. Schlager, and M.-C. Hofmann, "In vitro cytotoxicity of nanoparticles in mammalian germline stem cells," Toxicological Sciences, vol. 88, no. 2, pp. 412-419, 2005.

[28] W. W. Hwang-Verslues, W.-H. Kuo, P.-H. Chang et al., "Multiple lineages of human breast cancer stem/progenitor cells identified by profiling with stem cell markers," PloS ONE, vol. 4, no. 12, article e8377, 2009.

[29] R. Fuller, "Lead exposures from car batteries-a global problem," Environmental Health Perspectives, vol. 117, no. 12, article A535, 2009.

[30] J. Huang, K. Huang, L. Shang et al., "Chronic lead exposure reduces doublecortin-expressing immature neurons in young adult guinea pig cerebral cortex," BMC Neuroscience, vol. 13, article 82, 2012.

[31] R. A. Goyer and H. G. Seiler, Handbook on Toxicity of Inorganic Compounds, vol. 359, Marcel Dekker, New York, NY, USA, 1988.

[32] D. C. Bellinger and A. M. Bellinger, "Childhood lead poisoning: the torturous path from science to policy," Journal of Clinical Investigation, vol. 116, no. 4, pp. 853-857, 2006.

[33] K. Nemoto, S. Miyata, F. Nemoto et al., "Gene expression of neurotrophins and their receptors in lead nitrate-induced rat liver hyperplasia," Biochemical and Biophysical Research Communications, vol. 275, no. 2, pp. 472-476, 2000.

[34] D. G. Hicks, R. J. O’Keefe, K. J. Reynolds et al., "Effects of lead on growth plate chondrocyte phenotype," Toxicology and Applied Pharmacology, vol. 140, no. 1, pp. 164-172, 1996.

[35] H. Hu, M. Rabinowitz, and D. Smith, "Bone lead as a biological marker in epidemiologic studies of chronic toxicity: conceptual paradigms," Environmental Health Perspectives, vol. 106, no. 1, pp. 1-8, 1998.

[36] A. C. Todd, J. G. Wetmur, J. M. Moline, J. H. Godbold, S. M. Levin, and P. J. Landrigan, "Unraveling the chronic toxicity of lead: an essential priority for environmental health," Environmental Health Perspectives, vol. 104, no. 1, pp. 141-146, 1996. 
[37] G. Scholz, I. Pohl, E. Genschow, M. Klemm, and H. Spielmann, "Embryotoxicity screening using embryonic stem cells in vitro: correlation to in vivo teratogenicity," Cells Tissues Organs, vol. 165, no. 3-4, pp. 203-211, 1999.

[38] R. Cleymaet, P. Bottenberg, D. H. Retief, D. Slop, Y. Michotte, and D. Coomans, "In vivo use of a dual acid etch biopsy for the evaluation of lead profiles in human surface enamel," Caries Research, vol. 25, no. 4, pp. 256-263, 1991.

[39] R. Cleymaet, P. Bottenberg, D. Slop, R. Clara, and D. Coomans, "Study of lead and cadmium content of surface enamel of schoolchildren from an industrial area in Belgium," Community Dentistry and Oral Epidemiology, vol. 19, no. 2, pp. 107-111, 1991.

[40] R. Cleymaet, K. Collys, D. H. Retief et al., "Relation between lead in surface tooth enamel, blood, and saliva from children residing in the vicinity of a non-ferrous metal plant in Belgium," British Journal of Industrial Medicine, vol. 48, no. 10, pp. 702709, 1991.

[41] R. Cleymaet, E. Quartier, D. Slop, D. H. Retief, J. SmeyersVerbeke, and D. Coomans, "Model for assessment of lead content in human surface enamel," Journal of Toxicology and Environmental Health, vol. 32, no. 2, pp. 111-127, 1991.

[42] R. Cleymaet, D. H. Retief, E. Quartier, D. Slop, D. Coomans, and Y. Michotte, "A comparative study of the lead and cadmium content of surface enamel of Belgian and Kenyan children," Science of the Total Environment, vol. 104, no. 3, pp. 175-189, 1991.

[43] G. R. C. D. Almeida, M. D. C. Pereira Saraiva, F. Barbosa Jr. et al., "Lead contents in the surface enamel of deciduous teeth sampled in vivo from children in uncontaminated and in leadcontaminated areas," Environmental Research, vol. 104, no. 3, pp. 337-345, 2007.

[44] D. L. Jones and T. A. Rando, "Emerging models and paradigms for stem cell ageing," Nature Cell Biology, vol. 13, no. 5, pp. 506512, 2011.

[45] D. R. Bell and G. van Zant, "Stem cells, aging, and cancer: inevitabilities and outcomes," Oncogene, vol. 23, no. 43, pp. 7290-7296, 2004.

[46] E. M. Alissa and G. A. Ferns, "Heavy metal poisoning and cardiovascular disease," Journal of Toxicology, vol. 2011, Article ID 870125, 21 pages, 2011.

[47] N. C. Papanikolaou, E. G. Hatzidaki, S. Belivanis, G. N. Tzanakakis, and A. M. Tsatsakis, "Lead toxicity update. A brief review," Medical Science Monitor, vol. 11, no. 10, pp. RA329RA336, 2005.

[48] B. Assmus, T. Tonn, F. H. Seeger et al., "Red blood cell contamination of the final cell product impairs the efficacy of autologous bone marrow mononuclear cell therapy," Journal of the American College of Cardiology, vol. 55, no. 13, pp. 1385-1394, 2010.

[49] M. Prokopi, G. Pula, U. Mayr et al., "Proteomic analysis reveals presence of platelet microparticles in endothelial progenitor cell cultures," Blood, vol. 114, no. 3, pp. 723-732, 2009.

[50] M. Müller, O. Raabe, K. Addicks, S. Wenisch, and S. Arnhold, "Effects of non-steroidal anti-inflammatory drugs on proliferation, differentiation and migration in equine mesenchymal stem cells," Cell Biology International, vol. 35, no. 3, pp. 235-248, 2011.

[51] G. J. Long, J. F. Rosen, and J. G. Pounds, "Cellular lead toxicity and metabolism in primary and clonal osteoblastic bone cells," Toxicology and Applied Pharmacology, vol. 102, no. 2, pp. 346361, 1990.

[52] M. J. Zuscik, L. Ma, T. Buckley et al., "Lead induces chondrogenesis and alters transforming growth factor- $\beta$ and bone morphogenetic protein signaling in mesenchymal cell populations,"
Environmental Health Perspectives, vol. 115, no. 9, pp. 1276-1282, 2007.

[53] J. J. Carmouche, J. E. Puzas, X. Zhang et al., "Lead exposure inhibits fracture healing and is associated with increased chondrogenesis, delay in cartilage mineralization, and a decrease in osteoprogenitor frequency," Environmental Health Perspectives, vol. 113, no. 6, pp. 749-755, 2005.

[54] P. Chen, J. L. Carrington, R. G. Hammonds, and A. H. Reddi, "Stimulation of chondrogenesis in limb bud mesoderm cells by recombinant human bone morphogenetic protein $2 \mathrm{~B}$ (BMP$2 \mathrm{~B}$ ) and modulation by transforming growth factor $\beta 1$ and $\beta 2$," Experimental Cell Research, vol. 195, no. 2, pp. 509-515, 1991.

[55] D. A. Frenz, W. Liu, J. D. Williams et al., "Induction of chondrogenesis: requirement for synergistic interaction of basic fibroblast growth factor and transforming growth factor-beta," Development, vol. 120, no. 2, pp. 415-424, 1994.

[56] M. Iwasaki, K. Nakata, H. Nakahara et al., "Transforming growth factor- $\beta 1$ stimulates chondrogenesis and inhibits osteogenesis in high density culture of periosteum-derived cells," Endocrinology, vol. 132, no. 4, pp. 1603-1608, 1993.

[57] M. E. Joyce, A. B. Roberts, M. B. Sporn, and M. E. Bolander, "Transforming growth factor- $\beta$ and the initiation of chondrogenesis and osteogenesis in the rat femur," The Journal of Cell Biology, vol. 110, no. 6, pp. 2195-2207, 1990.

[58] P. Dalerba, S. J. Dylla, I.-K. Park et al., "Phenotypic characterization of human colorectal cancer stem cells," Proceedings of the National Academy of Sciences of the United States of America, vol. 104, no. 24, pp. 10158-10163, 2007.

[59] A. Rabbani-Chadegani, S. Abdosamadi, N. Fani, and S. Mohammadian, "A comparison of the effect of lead nitrate on rat liver chromatin, DNA and histone proteins in solution," Archives of Toxicology, vol. 83, no. 6, pp. 565-570, 2009.

[60] L. A. Loeb and R. A. Zakour, "Metals and genetic miscoding," in Nucleic Acid-Metal Ion InteractIon, T. G. Spiro, Ed., p. 115, John Wiley \& Sons, New York, NY, USA, 1980.

[61] M. J. McCabe Jr. and D. A. Lawrence, “The heavy metal lead exhibits B cell-stimulatory factor activity by enhancing B cell Ia expression and differentiation," The Journal of Immunology, vol. 145, no. 2, pp. 671-677, 1990.

[62] S. Maynard, A. M. Swistowska, J. W. Lee et al., "Human embryonic stem cells have enhanced repair of multiple forms of DNA damage," Stem Cells, vol. 26, no. 9, pp. 2266-2274, 2008.

[63] M. E. Gilbert, M. E. Kelly, T. E. Samsam, and J. H. Goodman, "Chronic developmental lead exposure reduces neurogenesis in adult rat hippocampus but does not impair spatial learning," Toxicological Sciences, vol. 86, no. 2, pp. 365-374, 2005.

[64] K. Jaako-Movits, T. Zharkovsky, O. Romantchik et al., "Developmental lead exposure impairs contextual fear conditioning and reduces adult hippocampal neurogenesis in the rat brain," International Journal of Developmental Neuroscience, vol. 23, no. 7, pp. 627-635, 2005.

[65] T. Verina, C. A. Rohde, and T. R. Guilarte, "Environmental lead exposure during early life alters granule cell neurogenesis and morphology in the hippocampus of young adult rats," Neuroscience, vol. 145, no. 3, pp. 1037-1047, 2007.

[66] T. M. DeLorey and R. W. Olsen, " $\gamma$-Aminobutyric acid(A) receptor structure and function," The Journal of Biological Chemistry, vol. 267, no. 24, pp. 16747-16750, 1992.

[67] N. Milosevic and P. Maier, "Lead stimulates intercellular signalling between hepatocytes and Kupffer cells," European Journal of Pharmacology, vol. 401, no. 3, pp. 317-328, 2000. 

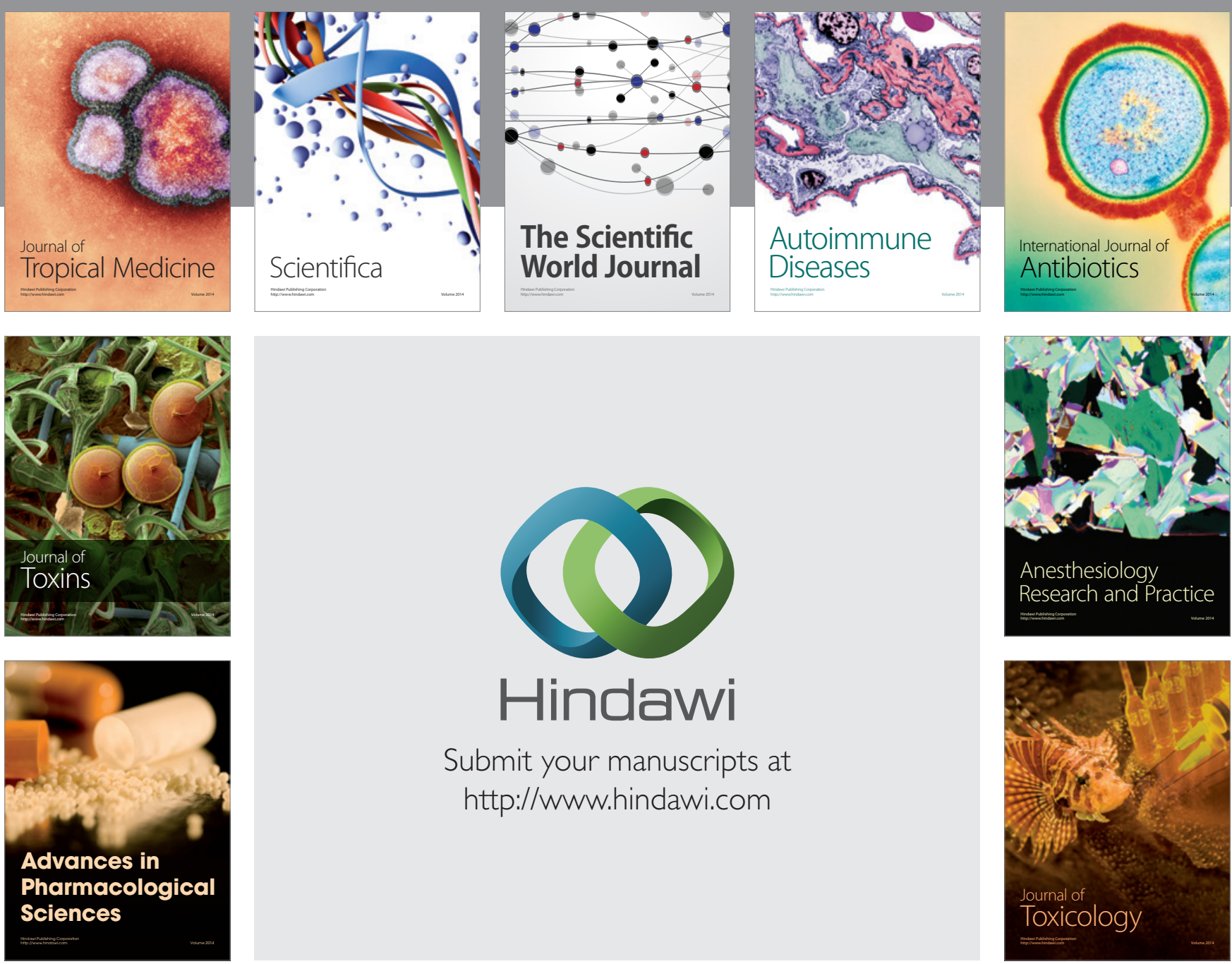

\section{Hindawi}

Submit your manuscripts at

http://www.hindawi.com
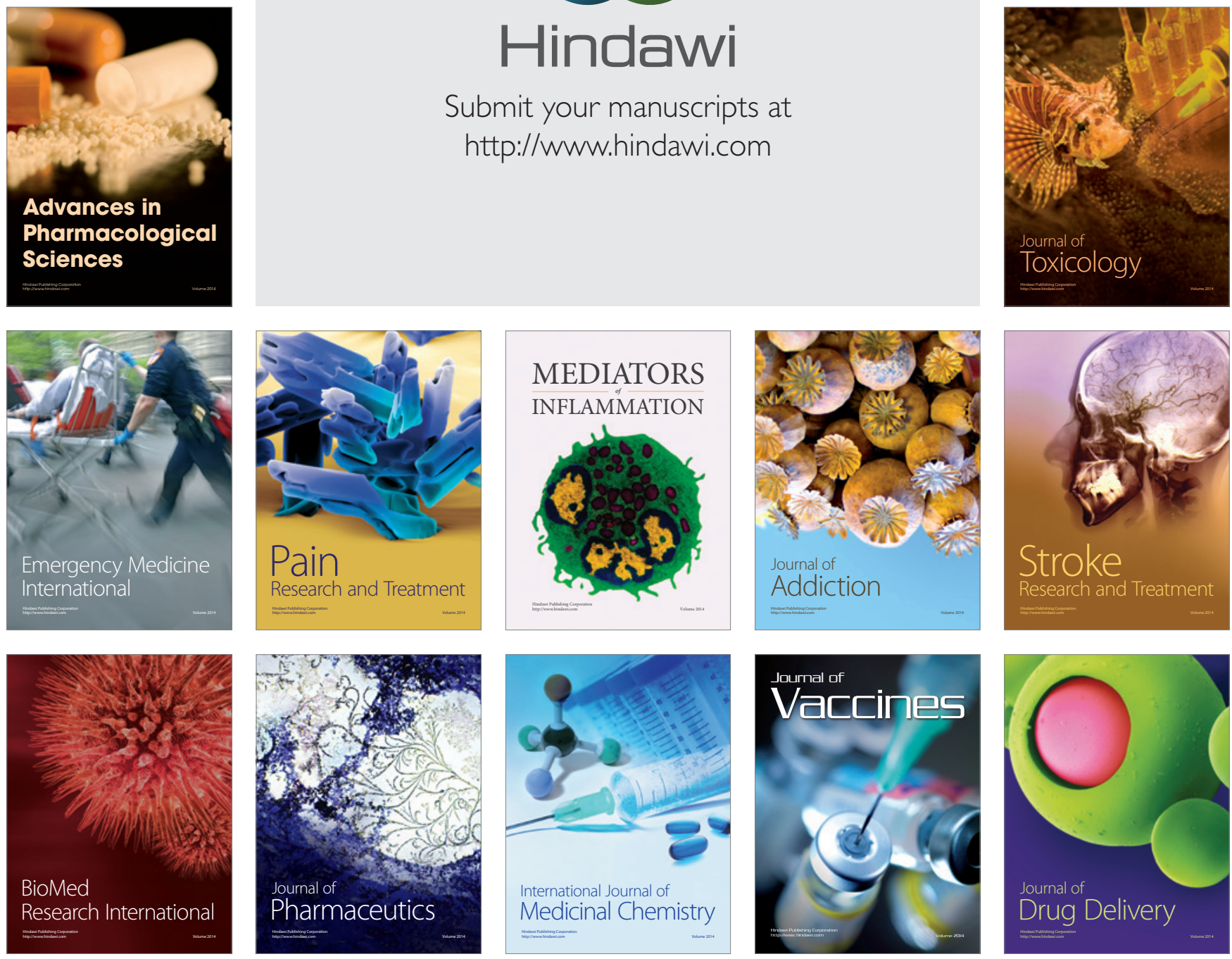